\title{
Validitas perangkat pembelajaran berbasis pbl dengan pendekatan konflik kognitif untuk membelajarkan kemampuan metakognisi
}

\author{
${ }^{1}$ Abdul Rais Nur, ${ }^{1}$ Saiful Prayogi, ${ }^{\star}{ }^{\star}$ Muhammad Asy'ari, ${ }^{3} \mathrm{M}$. Muhali \\ ${ }^{1}$ Program Studi Pendidikan Fisika, FSTT, Universitas Pendidikan Mandalika. \\ 2Program Studi Pendidikan Olahraga dan Kesehatan, FIKKM, Universitas Pendidikan Mandalika \\ ${ }^{3}$ Program Studi Pendidikan Kimia, FSTT, Universitas Pendidikan Mandalika \\ *Correspondence e-mail: muhammadasyari@ikipmataram.ac.id
}

\begin{abstract}
Abstrak: Tujuan penelitian ini adalah untuk mengetahui karakteristik perangkat pembelajaran berbasis Problem Based Learning (PBL) dengan pendekatan konflik kognitif untuk membelajarkan kemampuan metakognisi siswa. Penelitian ini merupakan penelitian deskriptif. Instrumen yang digunakan dalam penelitian ini berupa lembar validasi untuk mengevaluasi produk yang dihasilkan berupa silabus, rencana pembelajaran, lembar kegiatan siswa, dan tes pengetahuan metakognisi. Produk yang dihasilkan divalidasi oleh tiga validator ahli dan satu praktisi. Data dianalisis secara deskriptif menggunakan rerata skor yang diberikan validator. Hasil penelitian menunjukkan bahwa produk yang dikembangkan berupa silabus, rencana pembelajaran, lembar kegiatan siswa, dan tes pengetahuan metakognisi dinyatakan valid baik secara isi maupun konstruk sehingga dapat disimpulkan bahwa perangkat pembelajaran berbasis PBL dengan pendekatan konflik kognitif valid untuk membelajarkan kemampuan metakognisi.
\end{abstract}

Kata kunci: PBL, Konflik Kongitif, Kemampuan Metakongisi

\section{The validity of PBL based learning tools with cognitive conflict approaches to teach metacognition abilities}

\begin{abstract}
The purpose of this study was to determine the characteristics of Problem Based Learning (PBL) based learning tools with conflict-cognitive approach to teach students metacognition abilities. This research is descriptive research. The instrument used in this study was a validation sheet to evaluate the products in the form of a syllabus, lesson plans, student activity sheets, and tests of metacognition knowledge. The resulting products were validated by three expert validators and one practitioner. Data were analyzed descriptively using the mean score given by the validator. The results showed that the products developed in the form of syllabus, learning plans, student activity sheets, and metacognition knowledge tests were declared valid both in content and construct, so it can be concluded that PBL-based learning tools with conflict-cognitive approaches are valid for teaching metacognition abilities.
\end{abstract}

Keywords: PBL, Conflict-cognitive, Metacognition abilities

How to Cite: Nur, A., Prayogi, S., Asy'ari, M., \& Muhali, M. (2020). Validitas perangkat pembelajaran berbasis pbl dengan pendekatan konflik kognitif untuk membelajarkan kemampuan metakognisi. Empiricism Journal, 1(1), 111. doi:https://doi.org/10.36312/ej.v1i1.260

\section{PENDAHULUAN}

Pendidikan fisika merupakan rumpun mata pelajaran ilmu pengetahuan alam dan teknologi yang sangat penting dipelajari pada setiap tingakat satuan pendidikan yang meliputi pengetahuan, keterampilan, dan sikap serta kemampuan berpikir melalui interaksi langsung dengan sumber belajar yang dirancang dalam kegiatan pembelajaran. Kemampuan tersebut dapat diaplikasikan dengan baik ketika menggunakan model pembelajaran yang tepat dengan perkembangan pendidikan. Saat ini terdapat dua asesmen utama yang bersekala internasional yang menilai kemampuan matematika dan sains siswa, yaitu PISA (Program for Internatoinal Student Assessment) dan TIMSS (Trend in International Mathematics and Scinece Study).

Hasil studi Program for International Student Assessment (PISA), menunjukan peringakat Indonesia berada pada 10 besar terbawah dari 65 negara. Sedangkan hasil studi 
Trend in International Mathematics and Scinece Study (TIMSS) menunjukan siswa Indonesia berada pada ranking amat rendah dalam kemampuan (1) memahami informassi yang komplek, (2) teori, analisis dan pemecahan masalah, (3) pemakain alat, prosedur memecahkan masalah dan, (4) melakukan investigasi. Berdasrkan keriterian penilaian mencakup kemampuan kongitif dan keahlian membaca, matematika, dan sains. Hampir semua siswa Indonesia ternyata hanya menguasai pelajaran sampai level 3 saja (Husamah, 2013). Atas dasar uraian tersebut, perlu suatu perubahan dalam suatu kegiatan belajar mengajar. Perubahan itu memiliki tujuan untuk meningkatkan rasa ingin tahu siswa dan mendorong siswa untuk aktif kreatif dan inovatif.

Permendikbud No. 65 Tahun 2013 tentang Standar Proses Pendidikan Dasar dan Menengah disebutkan bahwa penyusunan perangkat pembelajaran merupakan bagian dari perencanaan pembelajaran. Perencanaan pembelajaran dirancang dalam bentuk silabus dan RPP yang mengacu pada standar isi. Selain itu, dalam perencanaan pembelajaran juga dilakukan penyiapan media dan sumber belajar, perangkat penilaian, dan skenario pembelajaran. Perangakat pembelajaran itu sendiri yaitu sebuah media yang digunakan sebagai pedoman atau petunjuk pada sebuah proses pembelajaran. Perangkat pembelajaran itu sendiri memiliki tujuan untuk memenuhi suatu keberhasilan guru dalam proses pembelajaran. Perangakat adalah sebuah sejumlah bahan, alat, media, petunjuk, dan pedoman yang akan digunakan dalam proses pencapaian kegiatan yang diinginkan. Perangkat pembelajaran adalah alat atau perlengkapan untuk melaksanakan proses yang memungkinkan pendidik dan peserta didik untuk melakukan kegiatan pembelajaran. Perangkat pembelajaran menjadi pegangan bagi guru dalam melaksanakan pembelajaran baik di dalam kelas, laboratorium atau diluar kelas (Prasetyo, 2011).

Pembelajaran yang inovatif diperlukan untuk mendukung kemampuan pemecahan masalah. Salah satu pembelajaran yang dapat diterapkan untuk membangun kemampuan pemecahan masalah ialah model problem based learning (PBL). Model pembelajaran berbasis masalah sangat efektif terhadap kemampuan pemecahan masalah (Noriza, Kartono, \& Sugianto, 2015) serta dapat meningkatkan kemampuan pemecahan masalah fisika (Abdullah, Mastur, \& Sutarto, 2015).

Pada dasarnya, setiap pembelajaran baik menggunakan model pembelajaran konvensional maupun model pembelajaran problem based learning dalam proses belajar mengajar selalu ada hambatan dan kendala. Salah satu kendala yang masih sering terjadi pada saat pembelajaran adalah ketika peserta didik masih mengalami kesulitan belajar sehingga peserta didik tidak mampu mencapai ketuntasan belajar. Untuk mengatasi kesulitankesulitan yang terjadi, maka setiap pembelajaran diakhiri dengan diagnostik yang gunanya untuk menganalisis kesulitan peserta didik. Sehingga dapat terdeteksi peserta didik manakah yang masih kesulitan pada materi yang diajarkan pada saat menggunakan model pembelajaran problem based learning. Seorang guru dalam pembelajaran harus mengenal dan memahami peserta didik dengan baik, memahami keunggulan dan kekurangannya (Satoto, Sutarto, \& Pujiastuti, 2012), serta hendaknya menganalisis kesulitan peserta didik terlebih dahulu sebelum melanjutkan pada materi berikutnya (Khaerunisak, Kartono, Hidayah, \& Fahmi, 2017).

Problem Based Learning (PBL) merupakan model pembelajaran yang menggunakan permasalahan atau fenomena dalam kehidupan sehari-hari yang telah ataupun yang akan dialami siswa sebagai stimulan dalam proses pembelajaran. Selain itu, karakter PBL yang menempatkan siswa pada situasi berbeda dengan pembelajaran konvesional dan mendorong pengembangan metakongisi siswa. PBL berkaitan dengan fenomena dalam kehidupan sehari-hari untuk merangsang siswa untuk termotivasi dalam memperoleh pengetahuan baru tentang konsep fisika (Tosun \& Senocak, 2013). Permasalahan tersebut dijadikan stimulan dalam PBL sebagai sarana untuk merangsang kesadaran metakongitif siswa dengan pemecahan masalah.

Salah satu model pembelajaran yang memperhatikan kesadaran metakongisi serta aktivitas penemuan pada siswa adalah model problem based learning (Adhitama, Kusnadi, \& Supriatno, 2018). PBL dapat diartikan sebagai rangkaian aktivitas pembelajaran yang menekankan pada proses penyelesaian masalah yang dihadapi secara ilmiah yaitu, dengan 
proses berpikir deduktif dan induktif yang dilakukan secara sistematis dan empiris (Crebert et al., 2011) yang terbukti berhasil secara empiris meningkatkan kemampuan memecahkan masalah siswa (Arimbawa, Sadia, \& Tika, 2013; Rufaida \& Sujiono, 2013; Sujarwanto, Hidayat, \& Wartono, 2014).

Perangkat pembelajaran pada penelitian ini menggunakan pendekatan konflik kongitif. Mischel (Ismaimuza, 2010) menyatakan, konflik kongitif adalah suatu situasi dimana kesadaran seorang individu mengalami ketidakseimbangan, ketidak seimbangan tersebut dapat disebabkan oleh adanya pertentangan antara kesadaran seseorang akan adanya informasi-informasi baru dengan informasi yang dimiliknya yang tersimpan dalam struktur kongitifnya tidak hanya dari masing-masing individu (Mischel, 2004), tetapi konflik kongitif dapat juga muncul dalam lingkungan sosial ketika ada pertentangan pendapat atau pemikiran antara seorang individu dengan individu yang lainya pada lingkungan individu yang bersangkutan (Damon \& Killen, 1982).

Hasil penelitian terdahulu menunjukkan bahwa pendekatan konflik kognitif dapat membuat siswa menjadi termotivasi dalam proses belajar (Sirait, 2012). Pembelajaran konflik kognitif terbukti sangat efektif tidak hanya pada hasil belajar kognitif siswa, tetapi dapat meningkatkan kemampuan berpikir kritis siswa. Dengan strategi pembelajaran yang menggunakan konflik kognitif dapat memberikan kesempatan kepada siswa untuk dapat berperan aktif dalam peroses pembelajaran, baik dalam mencari atau menemukan sendiri informasi yang berupa konsep dan teori serta kesimpulan dari konsep dan teori. Maka strategi pendekatan konflik kognitif sangat tepat diterapkan sebagai solusi untuk meningkatkan pemahaman konsep siswa dengan benar, karena dalam peroses pembelajarannya mengharuskan siswa untuk dapat membawa perubahan atau pemahaman dari ketidakseimbangan pada struktur kognitif siswa menuju konsep atau pemahaman yang lebih baik atau lebih tepat (Setyowati, Subali, \& Mosik, 2011).

Metakognisi merupakan karakteristik dasar dari kognisi manusia (Muhali, Yuanita, \& Ibrahim, 2019). Banyak para ahli dan peneliti yang memberikan definisi tentang metakognisi diantaranya metakognisi sebagai pengetahuan seseorang mengenai peroses berpikir dan hasil berpikirnya atau apapun yang berkaitan dengan peroses dan hasil berpikir tersebut (Flavell, 1979). Di pihak lain dijelaskan bahwa metakognisi adalah pengetahuan seseorang terhadap kemampuan mereka sendiri dalam mengolah informasi, maupun pengetahuan tentang tugas-tugas berpikir, dan tentang strategi untuk menyalin tugas-tugas yang serupa (Schneider \& Artelt, 2010). Metakognisi sebagai keteraampilan abad 21 sangat penting untuk dibelajarkan untuk membentuk siswa mandiri yang merupakan tujuan akhir dari pembelajaran (National Research Council, 2012).

Dengan demikian, dalam penelitian ini dilakukan dengan upaya untuk membelajarkan kemampuan metakognisi serta hasil belajar siswa melalui penerapan model PBL dengan pendekatan konflik kognitif yang dirancang untuk meningkatakan hasil belajar siswa dan membangun kesadaran dalam peroses pembelajaran dan mengembangkan pengetahuan baru dengan menggunakan metode pembelajaraan PBL dengan pendekatan konflik kognitif dalam implentasinya dilakukan pada fase satu memahami masalah dengan menyajikan konflik kognitif. Siswa juga diajarkan untuk belajar secara mandiri dan terlibat langsung secara aktif dalam pembelajaran kelompok. Dengan pembelajaran tersebut mampu membentuk siswa yang lebih mandiri dalam proses pembelajaran. Penelitian ini bertujuan untuk mendeskripsikan validitas perangkat pembelajaran PBL dengan pendekatan konflik kognitif untuk membelajarkan kemampuan metakognisi siswa pada materi Hukum Newton. Perangkat pembelajaran yang dimaksud dalam penelitian ini berupa silabus, rencana pembelajaran, lembar kegiatan siswa, dan tes pengtahuan metakognisi.

\section{METODE}

Penelitian ini merupakan penelitian deskriptif. Penelitian deskriptif merupakan penelitian yang dilakukan dengan tujuan utama untuk memberikan gambaran atau deskripsi tentang suatu keadaan secara objektif (Sukmadinata, N. S, 2010). Adapun kegiatan yang dilakukan dalam penelitian ini terdiri dari 3 (tiga) tahapan: (1) tahap perencanaan, (2) tahap pelaksanaan, dan (3) tahap mengevaluasi. 
Instrumen yang digunakan dalam penelitian ini berupa lembar validasi silabus, lembar validasi RPP, lembar validasi LKS, dan lembar validasi tes pengetahuan metakognisi yang telah dinyatakan valid (secara isi 0,715 , kontruk 0,745, muka 0,840) dan reliabel (isi: 0,834; konstruk: 0,854; dan muka: 0,840 (Muhali et al., 2019). Teknik pengumpulan data menggunakan teknik validasi oleh tiga validator ahli dan satu praktisi dengan memberikan penilaian pada lembar validasi silabus, lembar validasi RPP, dan lembar validasi LKS, serta lembar validasi tes kemampuan metakognisi.

Penilaian validitas perangkat pembelajaran dan tes pengetahuan metakognisi yang digunakan terdiri dari 4 skala penilaian yaitu, sangat kurang $=1$, kurang valid $=2$, valid $=3$, dan sangat valid $=4$. Skor yang diperoleh dari hasil penilaian dikonversi menjadi data kualitatif skala 4 (Ratumanan \& Laurens, 2012) dengan kriteria seperti pada Tabel 1.

Tabel 1. Kriteria Perangkat Pembelajaran dan Tes Pengetahuan Metakognisi Berdasarkan Rata-rata Nilai Validator

\begin{tabular}{cc}
\hline Interval Nilai & Kriteria \\
\hline$>3,6$ & Sangat Valid (SV) \\
$2,8-3,6$ & Valid (V) \\
$1,9-2,7$ & Tidak Valid (TV) \\
$1,0-1,8$ & Sangat Tidak Valid (STV) \\
\hline
\end{tabular}

Penilaian reabilitas intrumen dilakukan dari perhitungan rata-rata koefisien korelasi antar penilai (Cronbach's Alpha, $a$ ) dengan persamaan $a=k r_{a} /\left[1+(k-1) r_{a}\right]$. Produk dikatakan realibel jika memiliki percentage agreement sebesar $\geq 75 \%$, atau sebanyak $75 \%$ skor ratarata dari validator dengan kategori valid.

\section{HASIL PENELITIAN DAN PEMBAHASAN}

Hasil penelitian yang diperoleh berupa validitas perangkat pembelajaran model PBL dengan pendekatan konflik kognitif untuk membelajarkan kemampuan metakognisi siswa. Perangkat yang dimaksud adalah silabus, RPP, LKS, dan tes pengetahuan metakognisi. Perangkat pembelajaran tersebut divalidasi oleh para ahli dan praktisi yang memiliki kompetensi di bidang fisika maupun di bidang pendidikan dan pembelajaran. Validator yang melakukan penilaian terhadap perangkat pembelajaran terdiri dari 3 (tiga) ahli di bidang fisika dan/atau pembelajaran, dan 1 (satu) orang praktisi. Hasil penilaian para ahli dan praktisi terhadap perangkat berupa silabus, RPP, LKS, dan tes pengetahuan metakognisi diuraikan sebagai berikut.

\section{Validitas Silabus}

Validitas Silabus Model PBL dengan Pendekatan Konflik Kognitif untuk Membelajarkan Kemampuan Metakognisi. Silabus yang disusun mengacu pada standar isi sesuai kurikulum yang berlaku di SMA/MA meliputi identitas, kompetensi inti, kompetensi dasar, indikator, materi pokok, kegiatan pembelajaran, penilaian, alokasi waktu dan sumber belajar. Kompetensi Inti (KI) yang menjadi acuan dalam menyusun silabus terdiri dari 3 (tiga) ranah yang termuat dalam KI-1 sampai KI-4 yaitu: (1) sikap (spiritual dan sosial), (2) pengetahuan, dan (3) keterampilan, sedangkan kompetensi dasar (KD) pengetahuan yang menjadi acuan dalam penyusunan silabus adalah KD 3.4. Menganalisa hubungan antara gaya, massa, dan gerakan benda pada gerak lurus. Silabus yang dirancang berupa rencana pada suatu mata pelajaran mencakup beberapa komponen seperti KI, KD, materi pokok, indikator, alokasi waktu dan sumber belajar.

Tabel 2. Penilaian Validator terhadap Validitas Silabus Model PBL dengan Pendekatan Konflik Kognitif.

\begin{tabular}{clcccccc}
\hline \multirow{2}{*}{ No } & \multirow{2}{*}{ Aspek yang dinilai } & \multicolumn{9}{c}{ Penilaian Validator } & \multirow{2}{*}{ Rerata } & \multirow{2}{*}{ Ket. } \\
\cline { 3 - 6 } & & $\mathbf{1}$ & $\mathbf{2}$ & $\mathbf{3}$ & $\mathbf{4}$ & & \\
\hline 1 & Identitas Silabus & 4 & 3 & 3 & 4 & 3,5 & V \\
2 & Kompetensi Inti & 4 & 4 & 4 & 4 & 4 & SV \\
3 & Format Tabel dan Kompenen Isi & 4 & 4 & 4 & 4 & 4 & SV \\
& Tabel pada silabus & 4 & 3 & 3 & 4 & 3,5 & V
\end{tabular}




\begin{tabular}{clcccccc}
\hline \multirow{2}{*}{ No } & \multirow{2}{*}{ Aspek yang dinilai } & \multicolumn{9}{c}{ Penilaian Validator } & \multirow{2}{*}{ Rerata } & \multirow{2}{*}{ Ket. } \\
\cline { 3 - 7 } & & $\mathbf{1}$ & $\mathbf{2}$ & $\mathbf{3}$ & $\mathbf{4}$ & & \\
\hline 5 & Indikator & 4 & 3 & 3 & 4 & 3,5 & V \\
6 & Materi Pokok & 3 & 4 & 3 & 4 & 3,5 & V \\
7 & Kegiatan Pembelajaran & 4 & 4 & 3 & 4 & 3,75 & SV \\
8 & Penilaian & 3 & 4 & 3 & 4 & 3,5 & V \\
9 & Alokasi Waktu & 3 & 4 & 3 & 4 & 3,5 & SV \\
10 & Sumber Belajar & 4 & 4 & 4 & 4 & 4 & SV \\
\hline \multicolumn{7}{c}{ Reliabilitas } & \multicolumn{7}{c}{$96 \%$ (reliabel) } \\
\hline
\end{tabular}

Berdasarkan data validitas silabus pada Tabel 2, persentase nilai validitas rata-rata dari keempat validator pada setiap komponen penyusun silabus terdiri dari $50 \%$ dengan kategori sangat valid dan sebanyak $50 \%$ dengan kategori valid. Dengan demikian, secara umum silabus yang telah disusun dinyatakan valid, artinya bahwa silabus berbasis PBL dengan pendekatan konflik kognitif yang telah disusun dapat digunakan untuk membelajarkan kemampuan metakognisi siswa.

Silabus merupakan rencana pada suatu mata pelajaran yang mencakup beberapa komponen seperti KI, KD, materi pokok, indikator, alokasi waktu, penilaian dan sumber belajar. Hal tersebut menunjukkan bahwa silabus memiliki peran penting sebagai deskripsi pengetahuan, keterampilan dan kompetensi yang diajarkan selama proses pembelajaran. Berdasarkan hasil validasi silabus yang dapat dilihat pada Tabel 2, dapat diketahui bahwa secara keseluruhan, silabus yang dikembangkan memiliki rata-rata sebesar 3,8 (berkategori sangat valid) dengan persentasi reliabilitas sebesar $96 \%$ (berkategori reliabel). Hasil validasi ini menunjukkan bahwa silabus yang dikembangkan dapat digunakan pada tahap ujicoba terbatas. Hal ini menunjukkan bahwa silabus yang dikembangkan sudah sesuai sebagai rencana pembelajaran yang dapat membantu guru dalam menentukan kompetensi dan deskripsi pembelajaran yang dilaksanakan.

\section{Validitas Rencana Pembelajaran (RPP)}

Validitas RPP berbasis PBL dengan pendekatan konflik kognitif. Penyusunan RPP diturunkan dari silabus untuk mengarahkan kegiatan belajar siswa untuk mencapai kompetensi dasar (KD). Komponen-komponen yang termuat dalam RPP meliputi identitas mata pelajaran, kompetensi inti, kompetensi dasar, indikator, tujuan pembelajaran, materi ajar, alokasi waktu, model/metode, dan pendekatan, dan sumber belajar. Komponenkomponen RPP tersebut dijadikan dasar dalam proses pengujian validitas oleh ahli yang memiliki kompetensi di bidang pengajaran dan atau pembelajaran Fisika. Identitas mata pelajaran meliputi satuan pendidikan, kelas/semester, mata pelajaran, dan pertemuan. Penulisan $\mathrm{KI}$ dan KD sesuai dengan $\mathrm{KI}$ dan KD yang termuat dalam silabus. RPP yang dihasilkan dalam penelitian ini adalah sebanyak 3 (tiga) RPP, dan digunakan selama 3 (tiga) pertemuan, dengan alokasi waktu $2 \times 45$ menit. RPP pertemuan 1 membahas Hukum 1 Newton, pertemuan 2 membahas Hukum 2 Newton, dan pertemuan 3 membahas Hukum 3 Newton. Hasil penilaian ahli terhadap ketiga RPP dicantumkan dalam Tabel 3.

Tabel 3. Hasil Penilaian Validator terhadap RPP Model PBL dengan Pendekatan Konflik Kognitif

\begin{tabular}{|c|c|c|c|c|c|c|c|}
\hline \multirow{2}{*}{ No } & \multirow{2}{*}{ Aspek yang Dinilai } & \multicolumn{4}{|c|}{ Penilaian Validator } & \multirow{2}{*}{ Rerata } & \multirow{2}{*}{ Ket } \\
\hline & & 1 & 2 & 3 & 4 & & \\
\hline$A$ & Identitas RPP & & & & & & \\
\hline 1 & Komponen Identitas meliputi Judul, & & & & & & \\
\hline \multirow{3}{*}{$\begin{array}{l}B \\
2\end{array}$} & $\begin{array}{l}\text { satuan pendidikan, mata pelajaran, } \\
\text { kelas/semester, materi, dan alokasi } \\
\text { waktu. }\end{array}$ & 4 & 3 & 3 & 4 & 3,5 & V \\
\hline & Format/sistematika penulisan & & & & & & \\
\hline & $\begin{array}{l}\text { Komponen RPP terdiri dari identitas, } \\
\text { kompetensi inti, kompetensi dasar, } \\
\text { indikator dan tujuan, materi ajar, model, }\end{array}$ & 3 & 3 & 3 & 4 & 3,25 & V \\
\hline
\end{tabular}




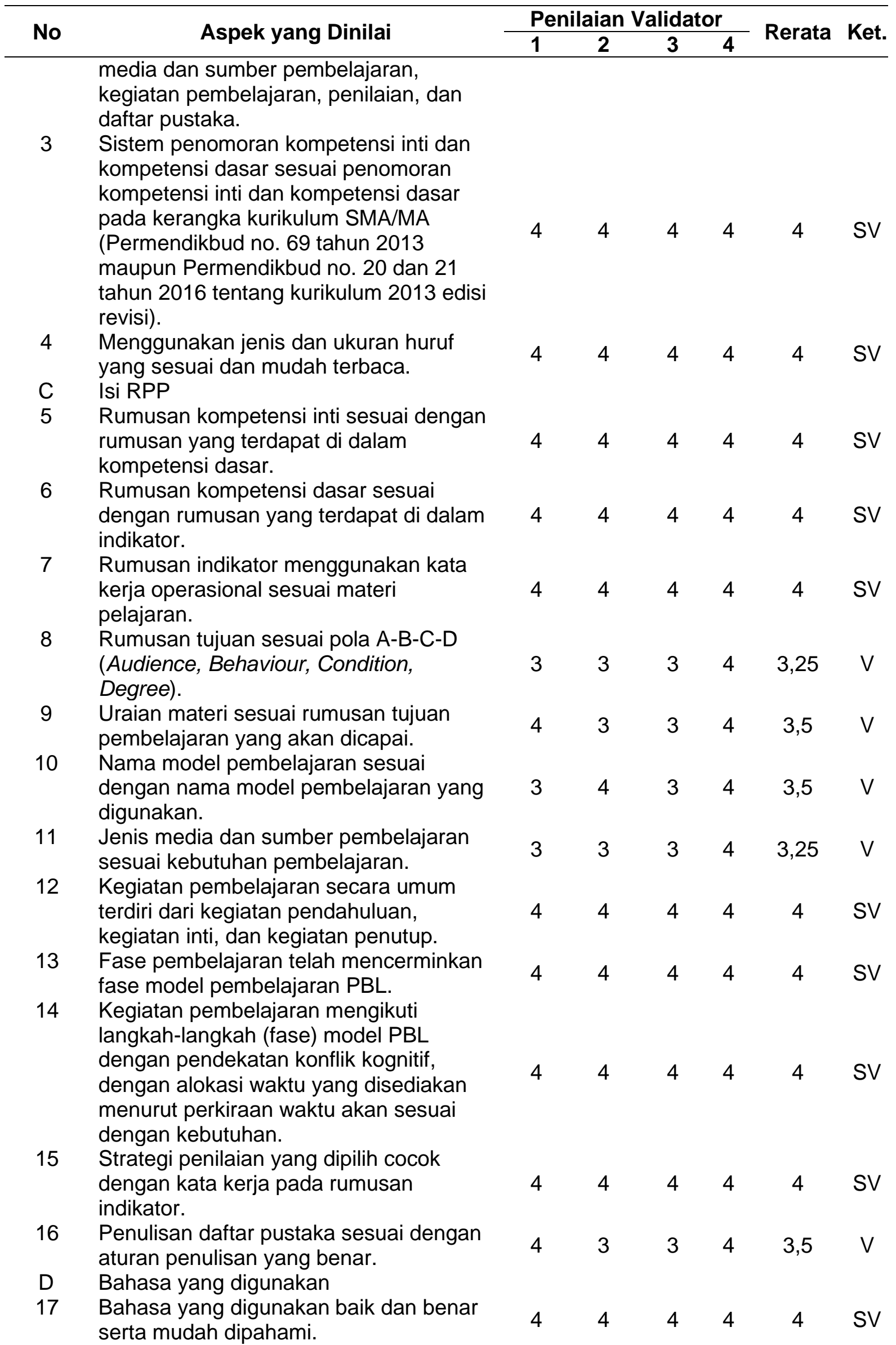




\begin{tabular}{rlrrrrrr}
\hline \multirow{2}{*}{ No } & \multicolumn{1}{c}{ Aspek yang Dinilai } & \multicolumn{3}{c}{ Penilaian Validator } & \multirow{2}{*}{ Rerata } & Ket. \\
\cline { 3 - 6 } 18 & $\begin{array}{l}\text { Penggunaan struktur kalimat yang baik } \\
\text { dan benar serta mudah dipahami. }\end{array}$ & 3 & 4 & 3 & 4 & 3,5 & V \\
19 & $\begin{array}{l}\text { Bahasa yang digunakan bersifat } \\
\text { komunikatif }\end{array}$ & 4 & 4 & 4 & 4 & 4 & SV \\
\hline Reliabilitas & \multicolumn{3}{c}{$97,74 \%$ (reliabel) } \\
\hline
\end{tabular}

Berdasarkan data validitas pada Tabel 3 , presentase nilai validitas rata-rata dari keempat validator pada setiap komonen penyusun RPP terdiri dari $72 \%$ dengan kategori sangat valid dan sebanyak $28 \%$ dengan kategori valid. Dengan demikian secara umum RPP yang telah disusun dinyatakan valid, artinya bahwa RPP dengan pendekatan konflik kongitif yang telah disusun dapat digunakan untuk membelajarkan kemampuan metakongisi siswa.

RPP model PBL dengan pendekatan konflik kognitif. RPP merupakan deskripsi mengenai materi yang diajarkan dan tindakan untuk mencapai tujuan pembelajaran yang telah ditentukan, disusun untuk mencapai kompetensi dasar (KD) dan mengacu pada silabus. Sama halnya dengan silabus, RPP yang dikembangkan sebelum dapat digunakan pada tahap ujicoba terlebih dahulu dilakukan uji validitas yang dilakukan oleh validator. Hal ini dilakukan guna mendapatkan RPP yang valid, baik, dan dapat digunakan pada tahap ujicoba terbatas. Berdasarkan hasil validasi RPP yang dikembangkan seperti yang ditunjukkan pada Tabel 3, secara keseluruhan penilaian validator terhadap RPP yang dikembangkan adalah sebesar 3,91 (berkategori sangat valid) dengan persentase reliabilitas $97,74 \%$ (berkategori reliabel). Hasil validasi ini menunjukkan bahwa RPP yang dikembangkan dapat digunakan pada tahap ujicoba terbatas. Komponen-komponen yang termuat dalam RPP meliputi identitas mata pelajaran, $\mathrm{KI}, \mathrm{KD}$, indikator, tujuan pembelajaran, materi ajar, alokasi waktu, model/metode, pendekatan pembelajaran, dan sumber belajar, serta penilaian. RPP yang dikembangkan dalam penelitian ini merupakan RPP berbasis PBL dengan pendekatan konflik kongitif. Tujuan dari pengembangan RPP ini adalah untuk melatihkan kemampuan metakognisi siswa, perangkat pembelajaran yang digunakan sebagai landasan untuk mengembangkan RPP dikarenakan perangkat pembelajaran berbasis $\mathrm{PBL}$ dengan pendekatan konflik kongitif menekankan pada proses berpikir secara mendalam, evaluatif, dan analitis untuk mencari dan menemukan sendiri jawaban dari suatu masalah yang dipertanyakan serta menyadari proses mendapatkan dan menggunakan informasi yang dimiliki.

\section{Validitas Lembar Kegiatan Siswa (LKS)}

LKS yang dihasilkan dalam penelitian ini sebanyak 3 (tiga) LKS, yakni LKS-01 digunakan untuk mengidentifikasi Hukum 1 Newton; LKS-02 digunakan untuk mengidentifikasi Hukum 2 Newton; LKS-03 digunakan untuk membahas Hukum 3 Newton. Hasil penilaian ahli terhadap LKS secara lengkap dapat dilihat pada pada Tabel 4.

Tabel 4. Hasil Validasi Lembar Kegiatan Siswa (LKS)

\begin{tabular}{|c|c|c|c|c|c|c|c|}
\hline \multirow[t]{2}{*}{ No } & \multirow[t]{2}{*}{ Aspek yang Dinilai } & \multicolumn{4}{|c|}{$\begin{array}{l}\text { Penilaian } \\
\text { Validator }\end{array}$} & \multirow[t]{2}{*}{ Rerata } & \multirow[t]{2}{*}{ Ket } \\
\hline & & 1 & 2 & 3 & 4 & & \\
\hline A & Format LKS & & & & & & \\
\hline 1 & $\begin{array}{l}\text { Memiliki kejelasan pembagian materi sesuai sub- } \\
\text { sub materi pada setiap pertemuan pembelajaran. }\end{array}$ & 4 & 4 & 4 & 4 & 4 & SV \\
\hline 2 & $\begin{array}{l}\text { Penyusunan LKS memiliki daya tarik bagi siswa } \\
\text { untuk belaiar. }\end{array}$ & 3 & 3 & 3 & 4 & 3,25 & V \\
\hline 3 & LKS menggunakan sistem penomoran yang jelas. & 4 & 4 & 4 & 4 & 4 & SV \\
\hline 4 & $\begin{array}{l}\text { LKS disusun sesuai pengaturan ruang/tata letak } \\
\text { yang jelas. }\end{array}$ & 4 & 4 & 4 & 4 & 4 & SV \\
\hline 5 & $\begin{array}{l}\text { Penulisan LKS menggunakan jenis dan ukuran } \\
\text { huruf yang sesuai. }\end{array}$ & 4 & 4 & 4 & 4 & 4 & SV \\
\hline 6 & $\begin{array}{l}\text { Daftar pustaka yang digunakan sesuai sumber } \\
\text { yang relevan dengan kebutuhan belajar siswa }\end{array}$ & 3 & 3 & 3 & 4 & 3,25 & V \\
\hline
\end{tabular}




\begin{tabular}{|c|c|c|c|c|c|c|c|}
\hline \multirow[t]{2}{*}{ No } & \multirow[t]{2}{*}{ Aspek yang Dinilai } & \multicolumn{4}{|c|}{$\begin{array}{l}\text { Penilaian } \\
\text { Validator }\end{array}$} & \multirow[t]{2}{*}{ Rerata } & \multirow[t]{2}{*}{ Ket } \\
\hline & & 1 & 2 & 3 & 4 & & \\
\hline $\mathrm{B}$ & Penggunaan Bahasa dalam LKS & & & & & & \\
\hline 7 & $\begin{array}{l}\text { LKS menggunakan bahasa yang benar sesuai } \\
\text { dengan tingkat pemahaman siswa. }\end{array}$ & 4 & 4 & 4 & 4 & 4 & SV \\
\hline 8 & $\begin{array}{l}\text { Kesesuaian bahasa dalam kalimat dengan tingkat } \\
\text { berpikir, kemampuan membaca, dan usia siswa. }\end{array}$ & 4 & 4 & 4 & 4 & 4 & SV \\
\hline 9 & $\begin{array}{l}\text { Bahasa yang digunakan dalam LKS mendorong } \\
\text { minat kerja siswa. }\end{array}$ & 3 & 3 & 3 & 4 & 3,25 & V \\
\hline 10 & $\begin{array}{l}\text { LKS menggunakan bahasa dengan struktur } \\
\text { kalimat yang sederhana. }\end{array}$ & 3 & 4 & 3 & 4 & 3,5 & V \\
\hline 11 & $\begin{array}{l}\text { Kalimat yang digunakan tidak mengandung } \\
\text { arti/makna ganda. }\end{array}$ & 4 & 4 & 4 & 4 & 4 & SV \\
\hline 12 & $\begin{array}{l}\text { LKS menggunakan bahasa yang sesuai dan jelas } \\
\text { pada setiap petunjuk/instruksi kerja. }\end{array}$ & 4 & 4 & 3 & 4 & 3,75 & SV \\
\hline 13 & $\begin{array}{l}\text { Bahasa yang digunakan pada LKS memiliki sifat } \\
\text { komunikatif sesuai perkembangan siswa. } \\
\text { Isi LKS }\end{array}$ & 4 & 3 & 3 & 4 & 3,5 & V \\
\hline 14 & $\begin{array}{l}\text { Rumusan tujuan pembelajaran sesuai dengan } \\
\text { rumusan tujuan pembelajaran pada RPP. }\end{array}$ & 3 & 3 & 3 & 4 & 3,25 & V \\
\hline 15 & $\begin{array}{l}\text { Materi LKS sesuai dengan rumusan tujuan } \\
\text { pembelajaran pada RPP }\end{array}$ & 4 & 4 & 4 & 4 & 4 & SV \\
\hline 16 & Materi sesuai konsep fisika yang benar. & 3 & 4 & 3 & 4 & 3,5 & $\mathrm{~V}$ \\
\hline 17 & $\begin{array}{l}\text { Materi pada LKS merupakan materi yang esensial } \\
\text { dalam kehidupan sehari-hari siswa. }\end{array}$ & 4 & 4 & 3 & 4 & 3,75 & SV \\
\hline 18 & $\begin{array}{l}\text { LKS dikelompokkan dalam bagian-bagian yang } \\
\text { logis sesuai dengan keterurutan kegiatan belajar } \\
\text { siswa dengan model reflektif-metakognitif. }\end{array}$ & 4 & 4 & 3 & 4 & 3,75 & SV \\
\hline 19 & $\begin{array}{l}\text { Materi sesuai dengan fase/kegiatan model PBL } \\
\text { dengan pendekatan konflik kognitif. }\end{array}$ & 4 & 4 & 3 & 4 & 3,75 & SV \\
\hline 20 & $\begin{array}{l}\text { Kesesuain tugas (pada LKS) dengan urutan } \\
\text { materi pada buku siswa. }\end{array}$ & 4 & 4 & 3 & 4 & 3,75 & SV \\
\hline 21 & $\begin{array}{l}\text { Isi LKS mampu mendorong siswa untuk } \\
\text { menemukan konsep. }\end{array}$ & 4 & 3 & 3 & 4 & 3,5 & V \\
\hline 22 & $\begin{array}{l}\text { Isi LKS dapat membelajarkan kemampuan } \\
\text { metakognisi. }\end{array}$ & 3 & 4 & 3 & 4 & 3,5 & V \\
\hline & & & & & & abel) & \\
\hline
\end{tabular}

Berdasarkan data validitas LKS pada Tabel 4, presentase nilai validitas rata-rata dari ke-empat validator pada setiap komponen penyusun LKS terdiri dari $97 \%$ dengan kategori sangat valid dan sebanyak 3\% dengan kategori valid. Dengan demikian, secara umum LKS yang telah disusun dinyatakan valid, artinya bahwa LKS berbasis PBL dengan pendekatan konflik kongitif yang telah disusun dapat digunakan untuk membelajarkan kemampuan metakongisi siswa.

Lembar Kegiatan Siswa (LKS) model pembelajaran PBL dengan pendekatan konflik kognitif. LKS merupakan salah satu perangkat pembelajaran yang mendukung tercapainya tujuan pembelajaran. LKS sebagai penunjang berhasilnya kegiatan pembelajaran dibedakan menjadi 2 (dua), yaitu LKS eksperimen dan non-eksperimen (Devi, Sofiraeni, \& Khairuddin, 2009). LKS yang dikembangkan dalam penelitian ini adalan LKS eksperimen pada materi hukum Newton. Berdasarkan hasil validasi LKS dan Kunci LKS yang dikembangkan seperti yang tampak pada Tabel 4 menunjukkan bahwa LKS yang dikembangkan valid dan dapat digunakan pada tahap ujicoba. Kevalidan LKS ini didukung oleh aspek/komponen yang menjadi kajian LKS yang dikembangkan, yang meliputi aspek format, bahasa, dan isi. 


\section{Validitas Tes Pengetahuan Metakognisi}

Instrumen tes pengetahuan metakognisi siswa digunakan untuk mengukur pencapaian pengetahuan deklaratif siswa, pengetahuan prosedural, dan pengetahuan kondisional. Instrumen terdiri dari 6 (enam) butir soal uraian pada materi Hukum Newton. Validitas dinilai oleh empat validator berkaitan dengan isi, bahasa dan penulisan instrumen. Hasil analisis validitas instrumen tes pengetahuan metakognisi disajikan pada Tabel 5.

Tabel 5. Hasil Penilaian Validitas Instrumen Tes Pengetahuan Metakognisi

\begin{tabular}{|c|c|c|c|c|c|c|c|c|c|c|c|c|}
\hline \multirow{4}{*}{$\begin{array}{c}\text { Nomor butir } \\
\text { soal }\end{array}$} & \multicolumn{12}{|c|}{ Aspek yang Dinilai } \\
\hline & \multicolumn{6}{|c|}{ Validasi Isi } & \multicolumn{6}{|c|}{ Validasi Bahasa dan Penulisan } \\
\hline & \multicolumn{4}{|c|}{ Penilaian } & \multirow{2}{*}{ Rerata } & \multirow{2}{*}{ Ket } & \multicolumn{4}{|c|}{ Penilaian } & \multirow{2}{*}{ Rerata } & \multirow{2}{*}{ Ket } \\
\hline & 1 & 2 & 3 & 4 & & & 1 & 2 & 3 & 4 & & \\
\hline 1 & 4 & 4 & 4 & 4 & 4 & SV & 4 & 4 & 4 & 4 & 4 & SV \\
\hline 2 & 4 & 4 & 4 & 4 & 4 & SV & 4 & 4 & 4 & 4 & 4 & SV \\
\hline 3 & 4 & 4 & 4 & 4 & 4 & SV & 4 & 4 & 4 & 4 & 4 & SV \\
\hline 4 & 4 & 4 & 4 & 4 & 4 & SV & 4 & 4 & 4 & 4 & 4 & SV \\
\hline 5 & 4 & 4 & 4 & 4 & 4 & SV & 4 & 4 & 4 & 4 & 4 & SV \\
\hline 6 & 4 & 4 & 4 & 4 & 4 & SV & 4 & 4 & 4 & 4 & 4 & SV \\
\hline Relibilitas (\%) & & & & & 97,43 & Reliabe & & iabi & s( & & 98,73 & Reliab \\
\hline
\end{tabular}

Berdasarkan data pada Tabel 5, instrumen pengetahuan metakognisi memenuhi validitas isi dikarenakan butir-butir pertanyaan sesuai dengan kisi-kisi soal yang telah dibahas bersama validator ahli dari bidang pendidikan dan bidang fisika, dan butir-butir pernyataan dapat mengukur pengetahuan metakognisi siswa. Pemenuhan validitas konstruk (bahasa dan penulisan soal) instrumen terlihat dari kesanggupan butir-butir pertanyaan untuk menilai ketertautan komponen indikator pengetahuan metakognisi dan tujuan pembelajaran.

\section{KESIMPULAN}

Berdasarkan hasil penelitian dan pembahasan, maka dapat disimpulkan sebagai berikut; (1) Perangkat pembelajaran berupa silabus, RPP, dan LKS, serta tes pengetahuan metakognisi dinyatakan valid dilihat dari: (a) persentase rerata skor penilaian berkategori valid dan sangat valid untuk komponen silabus masing-masing sebanyak $50 \%$; (b) persentase rerata skor penilaian berkategori valid dan sangat valid untuk komponen RPP sebanyak $28 \%$ dan $72 \%$; (c) persentase rerata skor penilaian berkategori valid dan sangat valid untuk komponen penyusun LKS sebanyak $3 \%$ dan $97 \%$; dan (d) persentase rerata skor penilaian berkategori sangat valid untuk komponen penyusun soal sebanyak $100 \%$. (2) Karakteristik perangkat pembelajaran berupa silabus, RPP, dan LKS secara umum dinyatakan valid. (a) Silabus berbasis PBL dengan pendekatan konflik kognitif: (1) komponen penyusun berupa KI, $\mathrm{KD}$, materi pokok, indikator, alokasi waktu, penilaian dan sumber belajar dinyataakan sangat valid; (2) aspek kompetensi (yang ingin dicapai) dalam $\mathrm{KI}, \mathrm{KD}$, dan indikator pembelajaran dinyatakan valid; (3) aspek yang berhubungan dengan cara yang ditempuh untuk menguasai kompetensi (kegiatan pembelajaran) dinyatakan valid, dan (4) aspek yang berhubungan dengan penilaian untuk mengetahui pencapaian siswa mengenai kompetensi yang diajarkan, dan aspek pendukung (alokasi waktu dan sumber belajar) dinyatakan valid. (b) RPP berbasis PBL dengan pendekatan konflik kognitif dinyatakan valid dilihat dari: (1) Komponen yang berhubungan dengan kompetensi yang ingin dicapai seperti yang tercantum pada KI, KD, indicator, dan tujuan pembelajaran, serta materi ajar; (2) komponen kegiatan pembelajaran yang mengacu pada sintaks atau fase pembelajaran model PBL dengan pendekatan konflik kognitif, di mana penyajian fenomena konflik kognitif pada fase kedua dan kelima; (3) komponen penilaian dan komponen pendukung meliputi strategi dan bentuk penilaian serta alokasi waktu. (c) LKS model PBL dengan pendekatan konflik kognitif dinyatakan valid dilihat dari: (1) aspek format meliputi tema, kesesuaian tujuan yang ingin dicapai dengan indikator, penulisan alat dan bahan yang dibutuhkan, dan petunjuk pengorganisasian pengerjaan LKS; (2) aspek isi meliputi materi dan kegiatan yang dilakukan siswa, serta memuat pertanyaanpertanyaan; (3) bahasa yang digunakan sesuai dengan tingkat perkembangan kognitif peserta didik, tidak memiliki makna ganda, dan mudah dimengerti, serta bersifat komunikatif. (d) Tes 
pengetahuan metakognisis dinyatakan valid baik secara isi, maupun bahasa dan penulisan pada soal-soal pengetahuan deklaratif, prosedural, dan kondisional.

\section{SARAN}

Berdasarkan penelitian yang telah dilakukan, maka saran yang dapat diberikan oleh peneliti yaitu sebagai berikut: (1) Perangkat pembelajaran yang dihasilkan pada penelitian ini perlu diujicobakan secara empiris pada siswa dalam belajar di kelas. (2) Perlu pengkajian karakteristik perangkat pembelajaran yang lebih spesifik untuk membelajarkan kemampuan metakognisi peserta didik.

\section{UCAPAN TERIMAKASIH}

Penelitian ini tidak menerima hibah khusus dari agensi pendanaan mana pun di sektor publik, komersial, atau nirlaba.

\section{DAFTAR PUSTAKA}

Abdullah, D. I., Mastur, Z., \& Sutarto, H. (2015). Keefektifan Model Pembelajaran Problem Based Learning Bernuansa Etnomatematika Terhadap Kemampuan Pemecahan Masalah Siswa Kelas Viii. Unnes Journal of Mathematics Education., 4(3). https://doi.org/10.15294/ujme.v4i3.9056

Adhitama, R. S., Kusnadi, K., \& Supriatno, B. (2018). Kesadaran Metakognitif Siswa dalam Pembelajaran Berbasis Proyek pada Pokok Bahasan Pencemaran Lingkungan. Assimilation: Indonesian Journal of Biology Education. https://doi.org/10.17509/aijbe.v1i1.11455

Arimbawa, P., Sadia, I. W., \& Tika, I. N. (2013). Pengaruh Model Pembelajaran Berbasis Proyek (MPBP) Terhadap Kemampuan Pemecahan Masalah IPA Sehari- Hari Ditinjau Dari Motivasi Berprestasi Siswa. Program Pascasarjana Universitas Pendidikan Ganesha.

Crebert, G., Patrick, C. J., Cragnolini, V., Smith, C., Worsfold, K., \& Webb, F. (2011). Griffith Graduate Attributes Teamwork Skills Toolkit. Griffith Graduate Attributes Teamwork Skills Toolkit.

Damon, W., \& Killen, M. (1982). Peer interaction and the process of change in children's moral reasoning. MerrillPalmer Quarterly.

Devi, Sofiraeni, \& Khairuddin. (2009). Pengembangan Perangkat Pembelajaran untuk Guru SMP. Jakarta: Pusat Pengembangan dan Pemberdayaan Pendidik dan Tenaga Kependidikan IImu Pengetahuan Alam (PPPPTK IPA) untuk Program Bermutu.

Flavell, J. H. (1979). Metacognition and cognitive monitoring: A new area of cognitivedevelopmental inquiry. American Psychologist. https://doi.org/10.1037/0003066X.34.10.906

Husamah. (2013). Blended Learning; Upaya Menyiapkan Calon Sarjana Pendidikan Biologi Berkarakter dan Melek Teknologi di Era Globalisasi. In Round Table Discussion Refleksi Pendidikan Akhir Tahun 2013.

Khaerunisak, K., Kartono, K., Hidayah, I., \& Fahmi, A. Y. (2017). THE ANALYSIS OF DIAGNOSTIC ASSESMENT RESULT IN PISA MATHEMATICAL LITERACY BASED ON STUDENTS SELF-EFFICACY IN RME LEARNING. Infinity Journal. https://doi.org/10.22460/infinity.v6i1.236

Mischel, W. (2004). Toward an integrative model for CBT: Encompassing behavior, cognition, affect, and process. Behavior Therapy. https://doi.org/10.1016/S0005-7894(04)80011-X

Muhali, Yuanita, L., \& Ibrahim, M. (2019). The validity and effectiveness of the reflectivemetacognitive learning model in improving students' metacognitive ability in Indonesia. Malaysian Journal of Learning and Instruction.

National Research Council. (2012). Scientific and engineering practices. In A framework for K-12 science education: Practices, crosscutting concepts, and core ideas. https://doi.org/978-0-309-21742-2

Noriza, M. D., Kartono, \& Sugianto. (2015). Kemampuan Pemecahan Masalah Dan Disposisi Matematis Siswa Kelas X Pada Pembelajaran Berbasis Masalah. Unnes Journal of 
Research Mathematics Education, 4(2), 66-75. Retrieved from http://journal.unnes.ac.id/sju/index.php/ujmer/article/view/9832

Prasetyo, Z. K. (2011). Pengembangan Perangkat Pembelajaran Sains Terpadu Untuk Meningkatkan Kognitif, Keterampilan Proses, Kreativitas Serta Menerapkan Konsep Ilmiah Peserta Didik Smp. Universitas Negeri Yogyakarta.

Ratumanan, T. G., \& Laurens, T. (2012). Evaluasi hasil belajar pada tingkat satuan pendidikan (Edisi 2). Surabaya: Unesa University Press.

Rufaida, S., \& Sujiono, E. H. (2013). Pengaruh model pembelajaran dan pengetahuan awalterhadap kemampuan memecahkan masalah fisikapeserta didik kelas xi IPA man 2 model Makassar. Jurnal Pendidikan IPA Indonesia. https://doi.org/10.15294/jpii.v2i2.2718

Satoto, S., Sutarto, H., \& Pujiastuti, E. (2012). Analisis Kesalahan Hasil Belajar Siswa Dalam Menyelesaikan Soal Dengan Prosedur Newman. Unnes Journal of Mathematics Education., 1(2). https://doi.org/10.15294/ujme.v1i2.1757

Schneider, W., \& Artelt, C. (2010). Metacognition and mathematics education. ZDM International Journal on Mathematics Education. https://doi.org/10.1007/s11858-0100240-2

Setyowati, A., Subali, B., \& Mosik. (2011). IMPLEMENTASI PENDEKATAN KONFLIK KOGNITIF DALAM PEMBELAJARAN FISIKA UNTUK MENUMBUHKAN KEMAMPUAN BERPIKIR KRITIS SISWA SMP KELAS VIII. Jurnal Pendidikan Fisika Indonesia, 7(2), 89-96. https://doi.org/10.15294/jpfi.v7i2.1078

Sirait, J. (2012). PENDEKATAN PEMBELAJARAN KONFLIK KOGNITIF UNTUK MENINGKATKAN PENGUASAAN KONSEP SISWA SMA PADA TOPIK SUHU DAN KALOR. Jurnal Pendidikan Matematika Dan IPA. https://doi.org/10.26418/jpmipa.v1i2.197

Sujarwanto, E., Hidayat, A., \& Wartono. (2014). Kemampuan pemecahan masalah fisika pada modeling instruction pada siswa sma kelas xi. Jurnal Pendidikan IPA Indonesia. https://doi.org/10.15294/jpii.v3i1.2903

Tosun, C., \& Senocak, E. (2013). The effects of problem-based learning on metacognitive awareness and attitudes toward chemistry of prospective teachers with different academic backgrounds. Australian Journal of Teacher Education. https://doi.org/10.14221/ajte.2013v38n3.2 